\title{
PENGENALAN PERAN AKUNTANSI DAN PELATIHAN PENYAJIAN LAPORAN KEUANGAN SEDERHANA PADA IBU-IBU BADAN KONTAK MAJELIS TAKLIM ILIR BARAT I PALEMBANG
}

\author{
Rifani Akbar Sulbahri'), Yuni Rachmawati²), Firmansyah Arifin ${ }^{3)}$ \\ 1),2),3) Prodi Akuntansi Universitas Tridinanti Palembang \\ Jalan Kapten Marzuki No.2446 Palembang, Kode Pos : 30129 \\ Email : rifaniakbar.sulbahri@yahoo.com ${ }^{1}$, yunirachmawatise@yahoo.com ${ }^{2}$, \\ Firmansyah.Arifin@ymail.com ${ }^{3}$
}

\begin{abstract}
ABSTRAK
Pengabdian Masyarakat merupakan salah satu pilar Tri Dharma PerguruanTinggi, disamping dharma pendidikan dan pengajaran serta dharma penelitian. Pengabdian Kepada Masyarakat juga merupakan suatu media untuk menjembatani dunia pendidikan dengan masayarakat, dimana Perguruan Tinggi dihadapkan pada masalah bagaimana agar warga masyarakat mampu menghadapi tantangan lebih jauh kedepan di era globalisasi. Organisasi Ibu-ibu BKMT Kecamatan Ilir Barat I diharapkan dapat memberdayakan wanita untuk turut berpartisipasi dalam pembangunan Kecamatan Ilir Barat I pada khususnya dan Indonesia pada umumnya dengan program pokok BKMT yaitu : Mengurangi masalah sosial, PKK, memberdayakan potensi ibu-ibu BKMT ilir Barat I Palembang, dan melakukan penyuluhan bidang pengembangan kelembagaan, dakwah, pendidikan, pelatihan, sosial, masyarakat, usaha, ekonomi, kesehatan, kerjasama dan humas terutama dalam membantu ekonomi keluarga sehingga lebih maju dan berkembang. Dalam pelaksanaan melakukan program kerja BKMT, Ibu-ibu BKMT Kec.Ilir Barat I Palembang sering menghadapi kendala dalam pembuatan laporan pertanggungjawaban dalam bentuk laporan keuangan bulanan maupun tahunan. Tujuan pengabdian ini adalah pemahaman tentang pentingnya akuntansi dalam kehidupan sehari-hari dan pengetahuan dan kemampuan menyajikan laporan keuangan sederhana bagi ibu-ibu BKMT Kecamatan Ilir Barat I Palembang, sehingga mereka bisa membuat laporan keuangan secara mandiri.Memberikan pelatihan pembuatan laporan keuangan sedarhana bagi Ibu-ibu BKMT Kecamatan Ilir Barat I Palembang guna meningkatkan kompetensi dan pemahaman mengenai tatacara pembuatan laporan keuangan sederhana yang pada akhirnya diharapkan Ibu-ibu BKMT Kecamatan Ilir Barat I nantinya dapat membuat laporan keuangan secara mandiri. Metode Penelitian adalah dengan menggunakan sistem workshop yaitu dengan menggunakan alat bantu seperti laptop dan LCD Proyektor serta di lanjutkan dengan sitem interaksi tanya jawab antara peserta dan narasumber.
\end{abstract}

Kata kunci: Laporan keuangan, Ibu-Ibu BKMT

\section{PENDAHULUAN}

Pengabdian Kepada Masyarakat merupakan salah satu pilar Tri Dharma Perguruan Tinggi, disamping dharma pendidikan dan pengajaran serta dharma penelitian. Pengabdian Kepada Masyarakat juga merupakan suatu media untuk menjembatani dunia pendidikan dengan masayarakat, dimana Perguruan Tinggi dihadapkan pada masalah bagaimana agar warga masyarakat mampu menghadapi tantangan lebih jauh ke depan di era globalisasi. Badan Kontak Majelis Taklim (BKMT) merupakan salah satu upaya untuk meningkatkan pengetahuan baik pengetahuan dibidang agama maupun pengetahuan umum ibu-ibu. Begitupula dengan ibu -ibu di Kecamatan Ilir Barat I Palembang, yang juga membentuk organisasi ini untuk melakukan pembinaan dan pegembangan ilmu dilingkungan Kecamatan Ilir Barat I Palembang. Organisasi Ibuibu BKMT Kecamatan Ilir Barat I diharapkan dapat memberdayakan wanita untuk turut berpartisipasi dalam pembangunan Kecamatan Ilir Barat I pada khususnya dan Indonesia pada umumnya dengan program pokok BKMT nya yaitu: Mengurangi masalah sosial, PKK, 
memberdayakan potensi ibu-ibu BKMT ilir Barat I Palembang, dan melakukan penyuluhan bidang pengembangan kelembagaan, dakwah, pendidikan, pelatihan, sosial, masyarakat, usaha, ekonomi, kesehatan, kerjasama dan humas terutama dalam membantu ekonomi keluarga sehingga lebih maju dan berkembang. Dalam pelaksanaan melakukan program kerja BKMT, Ibu-ibu BKMT Kec. Ilir Barat I Palembang sering menghadapi kendala, dalam pembuatan laporan pertanggung jawaban dalam bentuk laporan keuangan bulanan maupun tahunan.

Adanya masalah dalam pembuatan laporan keuangan ini disebabkan oleh kurangnya pemahaman ibu-ibu anggota BKMT terhadap laporan keuangan serta sebagian besar ibu-ibu yang menjadi anggota BKMT tidak memiliki kompetensi dibidang yang bersangkutan. Berdasarkan wawancara terhadap ibu-ibu anggota BKMT yang bertugas membuat laporan keuangan ditemukan bahwa salah satu penyebab kesulitan dalam pembuatan laporan keuangan disebabkan tidak adanya anggota BKMT yang memiliki basic pendidikan dibidang akuntansi atau dengan kompetensi dibidang pembuatan laporan keuangan. Sedangkan apabila harus menyerahkan pembuatan laporan keuangan kepada pihak luar BKMT sebagai pertanggung jawaban terhadap program-program yang dilaksanakan oleh BKMT, diperlukan biaya yang tidak sedikit dalam membuat laporan keuangan BKMT, dengan demikian, pengeluaran BKMT akan semakin banyak yang disebabkan oleh biaya jasa pembuatan laporan keuangan yang menggunakan pihak luar BKMT, sedangkan organisasi Ibu-ibu BKMT bukan merupakan organisasi yang mencari keuntungan, sehingga dirasa sangat menyulitkan finansial BKMT.

Melihat kenyataan yang ada dilapangan, perlu dan mendesaknya kebutuhan Ibu-ibu BKMT Kecamatan Ilir Barat I Palembang akan keterampilan membuat laporan keuangan, maka dirasa perlu adanya pelatihan pembuatan laporan keuangan sedarhana bagi Ibu-ibu BKMT Kecamatan Ilir Barat I Palembang guna meningkatkan kompetensi dan pemahaman mengenai tata cara pembuatan laporan keuangan sederhana yang pada akhirnya diharapkan Ibu-ibu BKMT Kecamatan Ilir Barat I nantinya dapat membuat laporan keuangan secara mandiri.

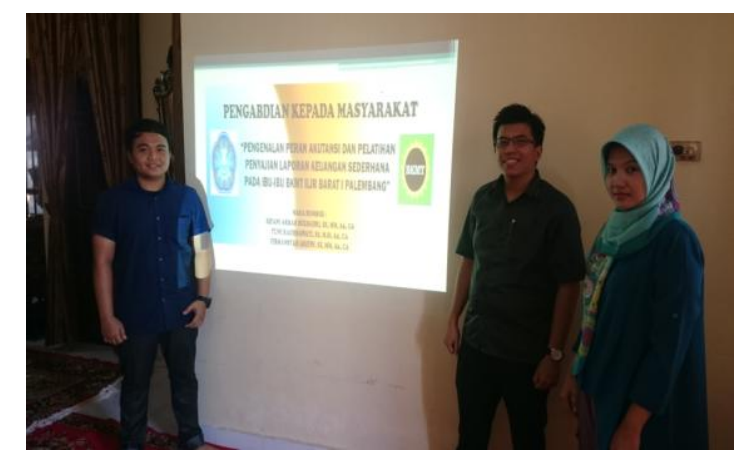

Gambar 1. Pelatihan Penyajian Laporan Keuangan

\subsection{Tujuan}

Tujuan yang ingin dicapai dalam pengabdian ini adalah pemahaman tentang pentingnya akuntansi dalam kehidupan sehari-hari dan pengetahuan dan kemampuan menyajikan laporan keuangan sederhana bagi ibu-ibu BKMT Kecamatan Ilir Barat I Palembang, sehingga mereka bisa membuat laporan keuangan secara mandiri.

\subsection{Manfaat kegiatan.}

Dengan adanya pengabdian ini diharapkan peserta (ibu-ibu BKMT Kecamatan Ilir Barat I Palembang) dapat menyajikan laporan keuangan secara mandiri sehingga pada akhirnya dapat digunakan untuk kepentingan user baik untuk jangka pendek maupun jangka panjang misalnya pengajuan pinjaman Bank.

\section{METODE PELAKSANAAN PENGABDIAN}

Metode yang dilakukan dalam kegiatan pengabdian kepada masyarakat ini adalah workshop dengan menggunakan alat bantu multimedia berupa laptop, dan LCD. Peserta yang yang 
merupakan anggota BKMT Kecamatan Ilir Barat 1 ini diharapkan setelah mengikuti workshop ini dapat mengetahui tata cara pembuatan laporan keuangan sederhana untuk masing-masing individu.

\subsection{Penyampaian Pengetahuan Mengenai Pembuatan Laporan Keuangan}

Dalam pengabdian ini, penulis menyampaikan materi sebagai berikut:

\subsubsection{Pengertian Laporan Keuangan}

Laporan keuangan adalah kesimpulan dari proses pembukuan yang menjadi dasar dalam mengetahui informasi posisi dan kinerja perusahaan. Laporan keuangan dibuat berdasarkan jurnal transaksi yang telah dibuat dan di posting ke dalam buku besar. Laporan ini terdiri dari empat bagian, yaitu neraca, laporan laba rugi, laporan perubahan modal, dan laporan arus kas (Weygandt, Jerry J., Kieso, Donald E, Paul D. 2012).

Komponen laporan keuangan meliputi neraca, laporan laba rugi, laporan posisi keuangan (yang dapata disajikan dalam berbagai cara contohnya sebagai laporan arus kas atau laporan arus dana), catatan dan laporan lainnya yang merupakan bagian integral dari laporan keuangan. Tujuan laporan keuangan adalah menyediakan informasi yang menyangkut posisi keuangan, kinerja serta perubahan posisi keuangan suatu entitas yang bermanfaat bagi sejumlah pemakai dalam pengambilan keputusan ekonomi. (SAK, 2007)

\section{1.2. Jenis Laporan Keuangan}

Laporan keuangan adalah laporan yang terdiri dari : laporan laba rugi, laporan perubahan modal, neraca, laporan arus kas, dan catatan atas laporan keuangan yang bertujuan memeberikan informasi kepada pihak ekternal dan internal perusahaan yang berkepentingan dengan perusahaan. (Munawir,2010:2). Terdapat lima bentuk laporan keuangan yang sering digunakan sebagai berikut :

1. Neraca

Munawir (2010:13) mengatakan bahwa neraca adalah laporan yang sistematis tentang aktiva, hutang serta modal dari suatu perusahaan pada suatu saat tertentu. Sehingga tujuan neraca adalah untuk menunjukkan keselarasan pada perusahaan pada saat tertentu, sehingga neraca sering disebut dengan balance sheet.

2. Laporan Laba Rugi

Munawir (2010:26) menjelaskan bahwa laporan laba rugi merupakan suatu laporan yang sistematis mengenail pendapatan, pengeluaran, rugi-laba yang diperoleh suatu perusahaan selama periode tertentu dan tingkat keefektifan manajemen menyerap dan menyalurkan dana.

3. Laporan Perubahan Modal

Laporan perubahan modal menggambarkan peningkatan dan penurunan modal awal selama periode bersangkutan berdasarkan prinsip pengukuran tertentu yang di anut dan harus di ungkapkan dalam laporan keuagan (Ikatan Akuntansi Indonesia,2009:24)

4. Laporan Arus Kas

Menurut Hanafi (2010:33) laporan arus kas menggambarkan aliran kas masuk dan aliran kas keluar pada suatu periode tertentu yang merupakan hasil dari kegiatan perusahaan yaitu operasional, investasi dan pendanaan. Laporan arus kas diperlukan karena dalam beberapa situasi, laporan laba-rugi tidak cukup akurat untuk menggambarkan kondisi yang diperoleh dari laporan keuangan perusahaan. Informasi yang diperoleh dari laporan ini dapat menunjukkan apakah perusahaan sedang maju atau mengalami financial distress.

5. Catatan atas Laporan Keuangan

Menurut Kennya Novya Putri Nugroho,et al (2016:22) Isi dari catatan atas laporan keuangan merupakan penjelasan umum tentang perusahaan, kebijakan akuntansi yang dianut dan penjelasan tiap-tiap akun dalam neraca dan laporan laba-rugi, laporan perubahan modal dan arus kas. 


\subsection{Tahapan Kegiatan Pengabdian}

Tabel 1. Tahapan Kegiatan

\begin{tabular}{|c|c|c|}
\hline $\begin{array}{l}12 \text { Mei 2016/ } \\
\text { Waktu }\end{array}$ & Materi & Penyaji \\
\hline $14.00-14.05$ & Pembukaan & TIM \\
\hline $14.05-14.20$ & Kata sambutan dari Ketua & Dra.Hj.Cholipa,MM \\
\hline & BKMT Kec Ilir Barat 1 & \\
\hline $14.20-14.40$ & Palembang & Syaiful Sahri, S.E., M.Si \\
\hline & Kata sambutan dari Dekan & \\
\hline $14.40-15.30$ & Fakultas Ekonomi Universitas & - Rifani Akbar Sulbahri,SE,MM., \\
\hline $15.30-16.00$ & Tridinanti Palembang & M.Ak., Ak,CA \\
\hline $16.00-16.15$ & Penyampaian materi & -Yuni Rachmawati,SE,MSi, Ak., CA \\
\hline $16.15-17.15$ & pengabdian & - Firmansyah Arifin, SE, MM., Ak \\
\hline & Sesi Tanya Jawab & TIM \\
\hline & $\begin{array}{l}\text { Penutup \& Doa } \\
\text { Ramah Tama dan Foto-Foto }\end{array}$ & TIM dan BKMT \\
\hline
\end{tabular}

Pengabdian Kepada Masyarakat (PKM) yang kami laksanakan di kediaman Ibu Dra.Hj.Cholipa,MM, Ketua BKMT Kecamatan Ilir Barat 1 diramaikan dengan sebuah lagu selamat datang dari kasidah. Kemudian dilanjutkan dengan kata Sambutan dari Ibu ketua dan Bpk Dekan Fakultas Ekonomi UTP dan selanjutnya penyampaian materi oleh ketiga anggota PKM. Ibu-Ibu BKMT Kecamatan Ilir Barat 1 Palembang sangat antusias terhadap materi yang disampaikan dalam pengabdian masyarakat ini. Materi disampaikan perhan-lahan, mengingat peserta bukan berlatar belakang ekonomi. Sejumlah pertanyaanpun diajukan oleh peserta dan langsung dijawab oleh Narasumber.
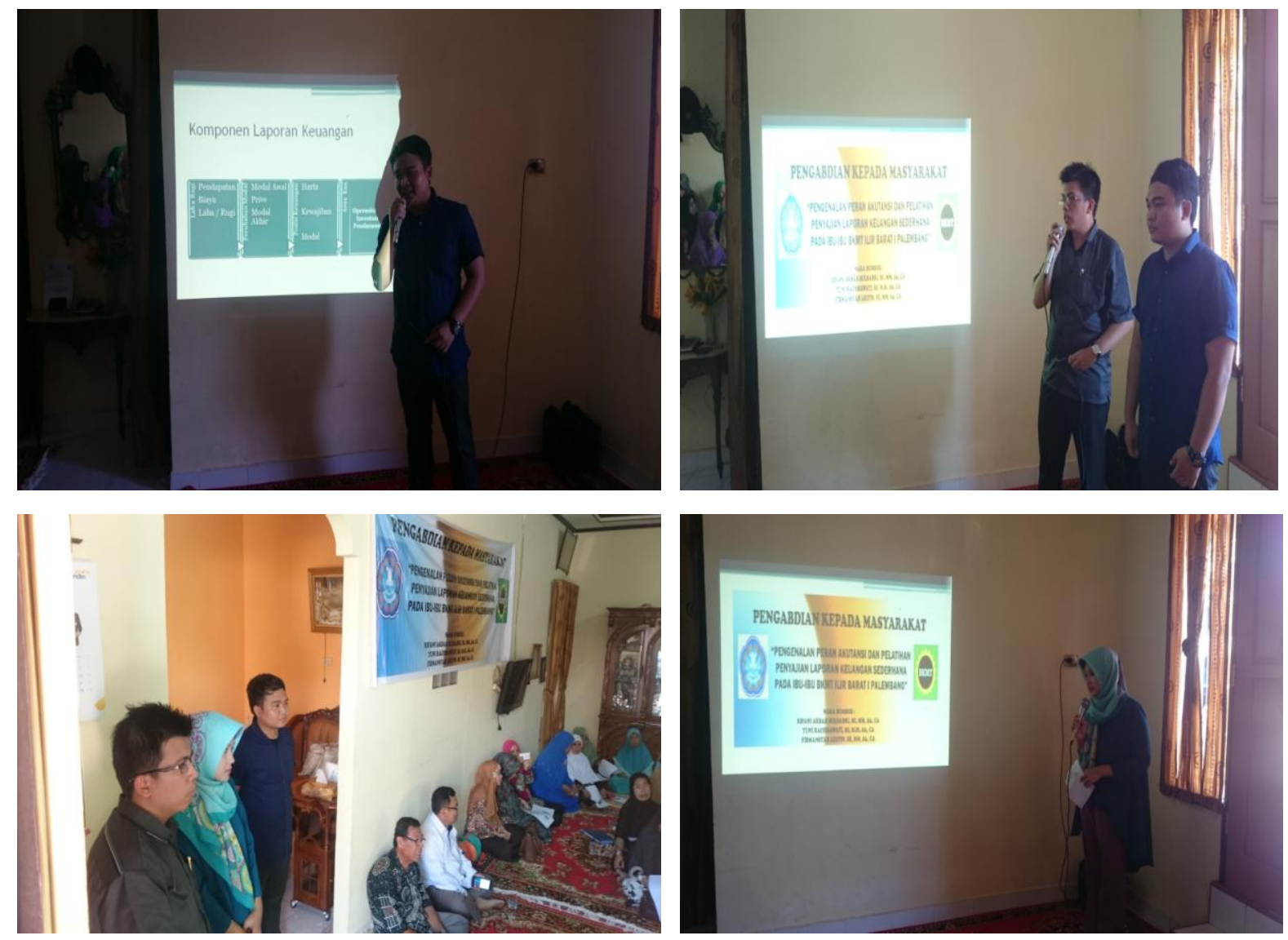

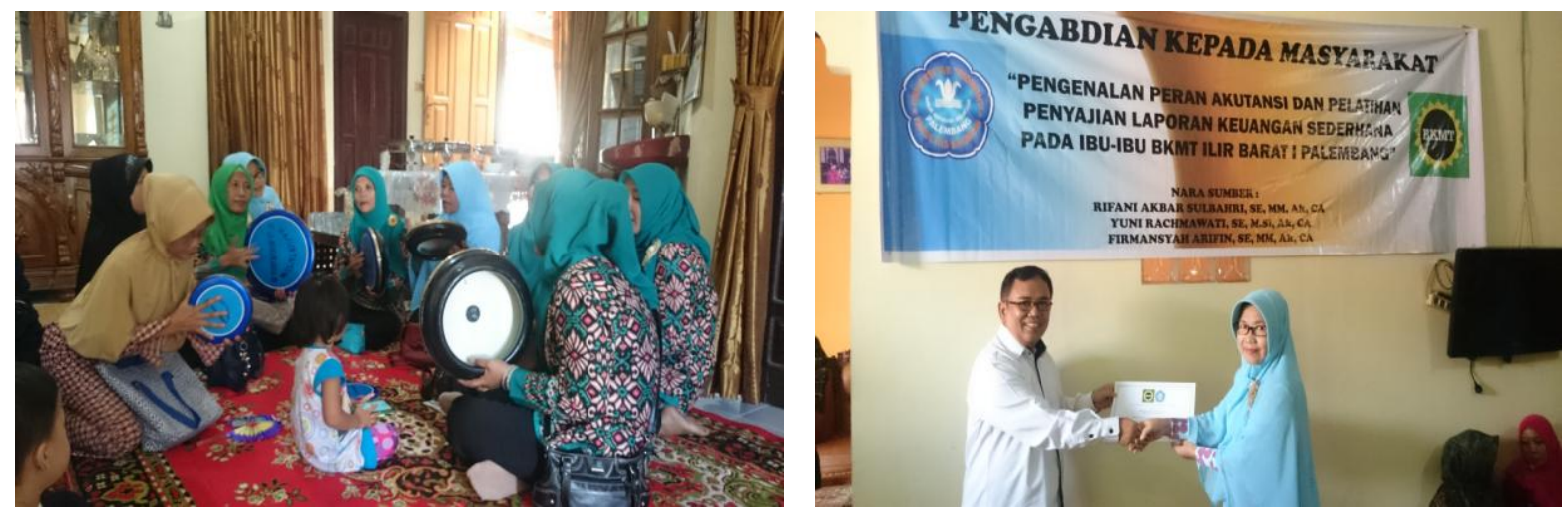

Gambar 2. Kegiatan acara pengabdian kepada masyarakat

\subsection{Kerangka Pemecahan Masalah}

Pentingnya pelatihan pembuatan laporan keuangan secara sederhana pada ibu-ibu BKM Taklim Ilir Barat I Palembang adalah dalam rangka mempersiapan sumber daya manusia yang telah handal dalam menghasilkan laporan keuangan sederhana yang berkualitas, bisa membuat neraca, laba rugi, laporan perubahan modal, laporan arus kas, dan catatan atas laporan keuangan ,serta proses pembuatannya demi mendukung tercapainya kemandirian dalam pembuatan laporan keuangan di BKM Taklim Ilir Barat I Palembang. Pelatihan satu hari tentang pembuatan laporan keuangan sederhana ini belum memadai untuk penyampaian materi tentang pembuatan laporan keuangan sederhana secara mendalam karena laporan keuangan tidak hanya sekedar dari aspek pembuatannya namun juga bagaimana melakukan pencatatan, mengklasifikasikan akun-akun maupun unsur-unsur neraca maupun laba rugi. Oleh sebab itu pelatihan kali ini merupakan langkah awal untuk mencapai tujuan yang lebih besar dari sekedar pelatihan pembuatan laporan keuangan secara sederhana.

\section{HASIL DAN PEMBAHASAN}

Ibu-Ibu BKMT kecamatan Ilir Barat 1 sebagian memang telah memiliki usaha namun masih belum tepat dalam menyajikan laporan keuangan. Belum adanya laporan keuangan yang handal ini membuat mereka menghadapi kendala pada saat mengajukan pinjaman kredit di Bank. Mereka telah menyerahkan laporan penerimaan dan pengeluaran ,namun tetap tidak mendapat persetujuan kredit dari pihak Bank karena mereka tidak dapat memberikan laporan keuangan yang sesuai standar keuangan yang berlaku umum di Indonesia. Belum terlaksananya pemisahan harta perusahaan dengan harta pemilk - bisnis entity menjadi salah satu contoh permasalahannya. Penerimaan dari penjualan kadang digunakan untuk kepentingan pribadi si pemilik, begitupula dengan pemakaian biaya untuk perusahaan seperti pemakaian kendaraan pribadi untuk mengangkut barang jualan dan sewa gedung yang tidak dibebankan sehingga tidak dapat diketahui laba usaha yang sebenarnya.

Antusias juga terlihat dari peserta ibu rumah tangga. Mereka juga dapat menggunakan laporan keuangan untuk mengatur keuangan rumah tangga agar pemasukan bisa tepat guna. Peserta disarankan untuk membuat daftar biaya yang akan dibayarkan untuk satu bulan, lalu dibandingkan dengan pemasukan dari keluarga. Dengan dibuatnya daftar biaya yang akan dibayar, dapat terlihat biaya yang tidak perlu dikeluarkan atau dapat ditunda jika keuangan tidak memungkinkan. Peserta dapat mengevaluasi biaya-biaya keluarga dan dapat mempertimbangkan peluang investasi atas kelebihan pemasukan tersebut. Begitupula dengan ibu-ibu yang baru akan membuka usaha, mereka dapat menggunakan ilmu akuntansi untuk memprediksi peluang dan sustainability usaha yang akan dibangun. Acara berjalan lancer dan bahkan masih ada peserta yang bertanya setelah acara ramah tamah telah selesai yakni sampai dengan pukul 18.00 WIB.

Setelah penyampaian dan tanya jawab selesai, nampak peningkatan pemahaman Ibu-Ibu BKMT Kecamatan Ilir Barat 1 tentang penyajian laporan keuangan sederhana. Mereka memahami 
akan pentingnya pemisahan harta perusahaan dengan harga pribadi dan akan mulai mengaplikasikannya. Mereka juga memahami bahwa laporan keuangan tidak hanya selembar kertas yang melaporkan penerimaan dan beban saja tetapi terdiri dari 4 komponen laporan keuangan yang juga melaporkan posisi harta perusahaan serta perubahan modal yang terjadi. Dengan adanya pengabdian kepada Ibu-Ibu BKMT kecamatan Ilir Barat 1 ini diharapkan dapat mengelola keuangan baik keuangan rumah tangga, maupun keuangan perusahaan/ usaha yang sedang digeluti sekarang dan diharapkan tidak menghadapi kendala lagi dalam hal pinjaman Bank.

\section{KESIMPULAN}

Berdasarkan hasil pelaksanaan kegiatan yang telah dilakukan, dapat ditarik beberapa simpulan sebagai berikut;

1. Pengetahuan ibu-ibu BKMT Kecamatan Ilir Barat 1 Palembang tentang pembuatan laporan keuangan sederhana masih sangat kurang. Hal ini diketahui dari beberapa pertanyaan pembuka yang disampaikan oleh penyaji yang belum bisa dijawab oleh peserta.

2. Penyampaian materi pembuatan laporan keuangan sederhana kepada peserta pelatihan dapat meningkatkan pengetahuan sekaligus sebagai stimulan agar ibu-ibu BKMT Kecamatan Ilir Barat 1 Palembang bisa secara mandiri membuat laporan keuangan untuk organisasinya.

\section{UCAPAN TERIMA KASIH}

Ucapan terimakasih penulis sampaikan kepada :

1. Yayasan Pendidikan Nasional Tridinanti Palembang yang telah membantu mendanai kegiatan PKM ini melalui hibah dana PKM bagi dosen di lingkungan Universitas Tridinanti Palembang.

2. Rektor Universitas Tridinanti Palembang, Ibu, DR.Ir.Hj.Manisah,MP. beserta staf.

3. Dekan Fakultas Ekonomi Tridinanti Palembang, Bpk Syaiful Sahri,SE,MSi

4. Ketua BKMT Ilir Barat I Palembang, Ibu.Dra.Hj.Cholipa,MM

5. Ibu-Ibu Anggota BKMT Ilir Barat I Palembang yang telah berpartisipasi secara aktif sebagai peserta

\section{DAFTAR PUSTAKA}

Hanafi, Mamduh. 2013. “Analisis Laporan Keuangan”. Yogyakarta : Penerbit UPP AMK. IAI. 2009. "Pedoman Standar Akuntansi Keuangan". Jakarta : Salemba Empat.

IAI. 2007. "Standar Akuntansi Keuangan (SAK)”, Salemba Empat, Jakarta.

Kennya Novya Putri Nugroho,et al . 2016. Penggunaan Analisis Z-score Altman Untuk Menilai Tingkat Financial Distress. Jurnal Administrasi Bisnis. Vol.36 Hal: 22

Munawir, S. 2010. Analisis Laporan Keuangan. Edisi Keempat. Yogyakarta:Liberty.

Weygandt, Jerry J., Kieso, Donald E, Paul E., Paul D. 2012. "Accounting Principles". twelve edition. Singapore: John Wiley \& Sons, inc 